\title{
Development and preliminary evaluation of a real-time PCR assay for Halioticida noduliformans in abalone tissues
}

\author{
Mariska R. Greeff ${ }^{1}$, Kevin W. Christison ${ }^{1,2}$, Brett M. Macey ${ }^{2, *}$ \\ ${ }^{1}$ Biodiversity and Conservation Biology, University of Western Cape, Private Bag X17, Bellville, South Africa \\ ${ }^{2}$ Department of Agriculture, Forestry and Fisheries, Directorate: Aquaculture Research, Private Bag X2, Roggebaai, \\ Cape Town, 8012, South Africa
}

\begin{abstract}
Abalone Haliotis midae exhibiting typical clinical signs of tubercle mycosis were discovered in South African culture facilities in 2006, posing a significant threat to the industry. The fungus responsible for the outbreak was identified as a Peronosporomycete, Halioticida noduliformans. Currently, histopathology and gross observation are used to diagnose this disease, but these 2 methods are neither rapid nor sensitive enough to provide accurate and reliable diagnosis. Realtime quantitative PCR (qPCR) is a rapid and reliable method for the detection and quantification of a variety of pathogens, so therefore we aimed to develop a qPCR assay for species-specific detection and quantification of $H$. noduliformans. Effective extraction of $H$. noduliformans genomic DNA from laboratory grown cultures, as well as from spiked abalone tissues, was accomplished by grinding samples using a pellet pestle followed by heat lysis in the presence of Chelax100 beads. A set of oligonucleotide primers was designed to specifically amplify $H$. noduliformans DNA in the large subunit (LSU) rRNA gene, and tested for cross-reactivity to DNA extracted from related and non-related fungi isolated from seaweeds, crustaceans and healthy abalone; no crossamplification was detected. When performing PCR assays in an abalone tissue matrix, an environment designed to be a non-sterile simulation of environmental conditions, no amplification occurred in the negative controls. The qPCR assay sensitivity was determined to be approximately $0.28 \mathrm{pg}$ of fungal DNA ( 2.3 spores) in a $25 \mu \mathrm{l}$ reaction volume. Our qPCR technique will be useful for monitoring and quantifying $H$. noduliformans for the surveillance and management of abalone tubercle mycosis in South Africa.
\end{abstract}

KEY WORDS: Abalone $\cdot$ Disease $\cdot$ Tubercle mycosis $\cdot$ Halioticida noduliformans $\cdot$ PCR Resale or republication not permitted without written consent of the publisher

\section{INTRODUCTION}

The abalone aquaculture industry in South Africa, which is based on the local species Haliotis midae, has grown rapidly in the last decade and South Africa is currently the largest producer of cultured abalone outside Asia (Bolton et al. 2009). Abalone aquaculture is also the largest of the marine aquaculture industries within South Africa, producing an estimated 913 US tons of cultured abalone in 2009, representing 93.9\% (ZAR320 million) of the total sales value of the marine aquaculture industry for that year (DAFF 2010). Haliotis midae exhibiting typical clinical signs of tubercle mycosis were however discovered in South African abalone culture facilities in 2006, posing a significant threat to the industry. The affected facilities suffered significant production losses, with up to $90 \%$ mortality among spat and up to $30 \%$ mortality among older animals, leading to the closure of 3 farms. The fungus responsible for the 
outbreak has been identified as a Peronosporomycete known as Halioticida noduliformans (Macey et al. 2011). Infected abalone are characterized by multifocal areas of necrosis of the epithelium and underlying muscle fibers, and connective tissues of the foot, epipodium and mantle. Currently, histopathology and gross observation are the 2 methods used to diagnose this disease, but they are not sensitive enough to provide accurate and reliable diagnosis. Molecular biological techniques, such as the polymerase chain reaction (PCR), could however provide for a more practical, specific, sensitive and rapid diagnosis of abalone tubercle mycosis in both clinically and sub-clinically infected animals that would facilitate management of this disease.

A number of direct and indirect methods exist for the quantification of environmental fungi, as well as other environmental microorganisms, and each method has certain advantages and disadvantages (Li et al. 1996, 1997). Culture-based methods are by far the most widely utilized, but these methods frequently underestimate the amount of or fail to detect the target organism in the environment (Wu et al. 2002, Oliver 2005, Macey et al. 2008a,b, Yamamoto et al. 2010). Culture-based methods rely on the isolation and maintenance of axenic cultures of the causative pathogen and often depend on further manipulations like the induction of zoosporogenesis for positive identification. These methods are time consuming, laborious and at risk of misidentifying species due to intra- and inter-specific variations in species morphological characteristics (Wu et al. 2002). Consequently, the use of culture-based techniques alone for disease management could be problematic. On the other hand, molecular biology techniques (indirect methods) have revolutionized the detection, identification and enumeration of microbes in complex ecosystems (Li et al. 1996). These methods are not dependent on the culturability or viability of the target organism and are more sensitive and precise (Yamamoto et al. 2010). This potentially allows for the detection of a disease-causing organism based on the presence of the pathogen DNA even before the clinical expression of the disease in the susceptible host or in a carrier host in which typical clinical signs are not exhibited.

Following the advent of the PCR technique, PCR has become a central technique in biochemistry and molecular biology and currently resides at the forefront of molecular diagnostic technology. PCR is highly sensitive with the capacity to amplify as little as a single or a few copies of a specific DNA sequence in a mixed genomic DNA background
(Zhou et al. 2000). However, even PCR has its shortfalls. Since amplification is not dependent on the culturability or viability of the target microorganism, and will generally occur provided that the segment of DNA is present (Zhou et al. 2000), distinguishing between microorganisms and spores that are viable, non-viable (i.e. metabolically inactive or dead), or in a viable but non-culturable (VBNC) state is not always possible. Furthermore, efficient cell lysis, DNA extraction and purification, choice of primers and PCR conditions are all sources of error for PCR-based detection and enumeration of microorganisms in the environment (Farrelly et al. 1995). Adequate attention must therefore be paid to the validation of PCR-based diagnostic techniques in order to avoid the occurrence of false positive and negative results.

Hiney \& Smith (1998) defined validation as 'a process that establishes the extent to which a technique generates meaningful data when it is applied, for a specific purpose, in a specific environmental context'. There are a number of factors that need to be considered at various levels of experimental complexity for validation of PCR-based techniques (Hiney \& Smith 1998, Bott et al. 2010). These include effective and repeatable extraction of genomic DNA from environmental samples, the identification of an appropriate DNA marker that is specific to the target organism, avoidance of PCR inhibition due to contaminants in environmental samples that will cause false negative results, and the optimization of molecular methods and procedures to avoid contamination of DNA that will contribute to false positive results (Bott et al. 2010). All of these factors also need to be accounted for at various levels of complexity (Hiney \& Smith 1998). The first level includes in vitro studies, where reactions are performed in a test tube so that the basic properties of the technique can be established. The second level is referred to as a seeded study in which reactions are performed in an environment or matrix that is designed to be a sterile simulation of the environmental conditions. The third level is referred to as an experimentally incurred matrix where laboratory-grown cells of the target organism are introduced into the environment and allowed to establish themselves, e.g. an experimental infection of a host organism. The fourth and final level of validation is the evaluation of the performance of the technique in a naturally infected environment (Hiney \& Smith 1998).

One of the most important aspects for the development of a reliable and robust PCR-based method is the identification of suitable DNA target regions. For 
identification of a specific target or pathogen, the selected DNA region should exhibit minimal genetic variation within a species but differ sufficiently between species to allow for unambiguous identification (Bott et al. 2010). Nuclear ribosomal DNA (rDNA) genes in a eukaryotic cell are repetitive, present in multiple copies and contain highly conserved sequences which can be used as primer templates for species-specific gene amplification ( $\mathrm{Li}$ et al. 1996, Zhou et al. 2000, Bott et al. 2010). Mitochondria are also highly abundant in cells and evolve at a quicker rate than nuclear genes, also making them particularly useful as species-specific markers for discriminating between closely related species. Ribosomal DNA and mitochondrial genes have consequently been widely utilized for the development of specific, sensitive and rapid PCR-based diagnostic techniques (Li et al. 1996, Zhou et al. 2000, Vandersea et al. 2006).

Effective management of abalone tubercle mycosis in South Africa, and elsewhere in the world, requires the development of techniques that will provide accurate and rapid identification of Halioticida noduliformans. Therefore, the primary objective of the present study was to develop a practical, specific, sensitive and rapid diagnostic tool that uses PCR to detect and identify $H$. noduliformans in infected abalone. In order to achieve this objective, methodology for the isolation of $H$. noduliformans genomic DNA from laboratory-grown cultures was established and optimized to yield high quality DNA with few or no PCR inhibitors. A real-time PCR assay was then developed and validated following many of the criteria proposed by Hiney \& Smith (1998) and Bott et al. (2010) in order to develop a diagnostic tool for effective surveillance and management of abalone tubercle mycosis in the South African abalone aquaculture industry.

\section{MATERIALS AND METHODS}

\section{Microorganisms and culture media}

Halioticida noduliformans was isolated from Haliotis midae obtained from an abalone culture facility in the Western Cape, South Africa (Macey et al. 2011). The sources, origins and strain designations of all other Peronosporomycete and non-Peronosporomycete isolates used to validate the PCR assay in this study are listed in Table 1. All isolates, with the exception of Aphanomyces astaci FDL 457, which was sourced as a freeze-dried culture from the United Kingdom (Oidtmann et al. 2004), were cultured using aseptic technique by transferring small pieces of tissue $\left(<2 \mathrm{~mm}^{3}\right)$ onto Petri dishes containing marine Phycomycete isolation agar (Fuller et al. 1964), supplemented with streptomycin sulphate and penicillin $(0.05 \% \mathrm{wt} / \mathrm{vol})$ to retard bacterial growth. Inoculated plates were incubated at $20^{\circ} \mathrm{C}$ and monitored daily for growth. Following 7 to $10 \mathrm{~d}$ incubation, emerging hyphal tips were aseptically transferred onto fresh plates of marine Phycomycete isolation agar. This procedure was repeated until the cultures were free of contamination. Once pure cultures were obtained, fungi were transferred and maintained at $20^{\circ} \mathrm{C}$ on peptone-yeast-glucose-saline (PYGS) agar, which was made of $0.125 \% \mathrm{wt} / \mathrm{vol}$ yeast extract, $0.125 \%$ peptone, $0.3 \%$ D-glucose, $1.2 \%$ bacteriological agar made up in natural seawater $(35 \%)$, without antibiotics, and routinely subcultured once every 2 to $3 \mathrm{wk}$.

Table 1. Peronosporomycete and non-Peronosporomycete isolates used for real-time PCR assay optimization

\begin{tabular}{|c|c|c|c|c|c|}
\hline Species & Isolate & Host & $\begin{array}{l}\text { Location of } \\
\text { sample collection }\end{array}$ & GenBank no. & Source \\
\hline Unidentified Pleosporales & PG170709B1 & Palinurus gilchristi & Western Cape & JN397388 & This study \\
\hline Acremonium sp. & PG170709B2 & Palinurus gilchristi & Western Cape & JN397389 & This study \\
\hline Unidentified Pleosporales & PG170709B3 & Palinurus gilchristi & Western Cape & JN397390 & This study \\
\hline Hypocreales sp. & Kelp100210A & Ecklonia maxima & Western Cape & JN397391 & This study \\
\hline Hypocreales sp. & Kelp100210B & Ecklonia maxima & Western Cape & JN397392 & This study \\
\hline Fusarium sp. & SC110909A & Macrocheira kaempferi & Western Cape & JN397393 & This study \\
\hline Microascus sp. & SC230909 & Macrocheira kaempferi & Western Cape & JN397394 & This study \\
\hline Hypocreales sp. & SCG230909 & Macrocheira kaempferi & Western Cape & JN397395 & This study \\
\hline Aphanomyces astaci & FDL 457 & Crayfish & United Kingdom & DQ 403202.1 & $\begin{array}{l}\text { Oidtmann } \\
\text { et al. (2004) }\end{array}$ \\
\hline Halioticida noduliformans & AF08527 & Haliotis midae & Western Cape & GU289906 & $\begin{array}{l}\text { Macey et } \\
\text { al. (2011) }\end{array}$ \\
\hline
\end{tabular}




\section{Sample preparation}

For the preparation of large quantities of mycelia for genomic DNA extraction, agar plugs (2 to $3 \mathrm{~mm}$ in diameter) of actively growing mycelia $(7 \mathrm{~d}$ old culture) were transferred from culture plates into separate autoclaved glass test tubes containing $5 \mathrm{ml}$ sterile PYGS broth (PYGS without agar) and incubated at $20^{\circ} \mathrm{C}$ for 10 to $14 \mathrm{~d}$. Following incubation, actively growing colonies were rinsed 3 times with sterile filtered seawater and transferred to sterile $100 \mathrm{~mm}$ Petri dishes. Hyphal tips (10 to $20 \mathrm{mg}$, wet wt) were excised with a scalpel blade and transferred to preweighed microcentrifuge tubes. Samples were kept on ice until needed.

\section{Optimization of DNA extraction conditions from laboratory-grown cultures}

To optimize DNA extraction conditions, known quantities of Halioticida noduliformans mycelia were subjected to a variety of cell-wall disruption and lysis methods. The degree of fungal cell-wall disruption and lysis was first visually assessed and then later quantified by determining the yield of DNA in each extract recovered using the isopropanol method described below. Thereafter, the best cell-wall disruption and lysis method was used to further optimize extraction conditions by testing 3 different DNA extraction and recovery methods, namely phenolchloroform, isopropanol and heat lysis. To examine the DNA yield in each extract, the isolated DNA was quantified with a Libra S12 spectrophotometer (Biochrom) and DNA quality was tested by $0.8 \%$ agarose gel electrophoresis. A total of 6 to 10 samples were tested for each method and the data recorded as the mean $( \pm \mathrm{SE})$ DNA concentration per mass of starting material for each treatment. Specific procedures are described below.

Fungal cell-wall disruption methods

Since cell-wall disruption constitutes the first step in extracting good quality DNA, we tested and compared 3 physical disruption methods to determine the breakage efficiencies of each on mycelium cell walls. These methods included (1) fine bead homogenization, (2) grinding with a conical grinder, and (3) liquid nitrogen freezing followed by grinding with a conical grinder. Mycelia were prepared as described above and a total of 6 samples were tested for each physical disruption method. All procedures were performed on ice to prevent any degradation of genetic material.

For (1), $300 \mu \mathrm{l}$ extraction buffer (17.34 mM sodium dodecyl sulfate [SDS]; $50 \mathrm{mM}$ Tris; $0.4 \mathrm{M}$ EDTA, $\mathrm{pH}$ 8.0) and $0.3 \mathrm{~g}$ sterile glass beads (Sigma, Catalog \#G8772) were added to each sample and vortexed for $10 \mathrm{~min}$. For (2), $300 \mu \mathrm{l}$ extraction buffer was added to each microcentrifuge tube prior to grinding the samples at $250 \mathrm{rpm}$ for $1 \mathrm{~min}$ using a Caframo BDC1850 stirrer equipped with a pellet pestle (www.caframo. com). Finally, for (3), samples were first submerged in liquid nitrogen to flash-freeze mycelia before grinding each sample as described above. Care was taken to keep the latter samples frozen throughout this process. Extraction buffer $(300 \mu l)$ was added to each sample immediately after the grinding step for this method.

Following each of the physical disruption procedures described above, cell-wall disruption was initially subjectively assessed and categorized according to Karakousis et al. (2006) by observing mycelia from each sample under $400 \times$ magnification using an Olympus BX51 light microscope, and comparing to untreated cultures as controls. The amounts of cell breakage and lysis observed in samples were expressed as percentages falling within the following categories: (1) for samples with none to minimal (0 to $25 \%$ ) cell lysis, (2) if some breakage of mycelia (25 to $50 \%$ ) was observed in the sample, (3) if most of the hyphae (50 to $75 \%$ ) were lysed, and finally (4) if almost complete cell-wall breakage ( 75 to $100 \%$ ) was observed in the sample (Karakousis et al. 2006). Immediately thereafter, genomic DNA was extracted from each sample using the isopropanol method described below to allow for a more objective comparison of breakage efficiencies between samples, and the data were recorded as the mean $( \pm \mathrm{SE}, \mathrm{n}=6)$ DNA concentration per mass of starting material for each mechanical disruption method.

Enzymatic digestion methods

Mycelia, prepared as described above, were ground in $300 \mu \mathrm{l}$ extraction buffer with a conical grinder at $250 \mathrm{rpm}$ for $1 \mathrm{~min}$ before adding $400 \mathrm{U}$ lyticase (Sigma, Catalog \#L4025) or $10 \mu g$ Proteinase $\mathrm{K}$ (Sigma, Catalog \#P4850) and incubating for $1 \mathrm{~h}$ at $30^{\circ} \mathrm{C}$ and $55^{\circ} \mathrm{C}$, respectively. Each treatment, including controls without enzyme, consisted of 10 samples. Following incubation, genomic DNA was extracted from each sample using the isopropanol 
extraction method described below and the data were recorded as the mean $( \pm \mathrm{SE}, \mathrm{n}=10)$ DNA concentration per mass of starting material for each enzyme treatment and the control.

\section{Fungal DNA extraction and recovery methods}

Mycelia were ground in $300 \mu$ l of extraction buffer with a conical grinder at $250 \mathrm{rpm}$ for $1 \mathrm{~min}$ before recovering total genomic DNA using 2 different methods. A simple heat lysis method was also tested for extraction and recovery of DNA.

Phenol:chloroform:isoamyl alcohol method. Phenol:chloroform:isoamyl alcohol (25:24:1; $500 \mu \mathrm{l})$ was added to each crude extract $(n=6)$ and centrifuged at $5000 \times g$ for $10 \mathrm{~min}$. Supernatants were carefully removed with a widebore $1 \mathrm{ml}$ tip, transferred to new sterile $1.5 \mathrm{ml}$ microcentrifuge tubes before adding $500 \mu \mathrm{l}$ chloroform, and finger vortexed. Supernatants were again removed using widebore $1 \mathrm{ml}$ tips and transferred to new sterile $1.5 \mathrm{ml}$ microcentrifuge tubes before adding 0.1 volumes of $3 \mathrm{M}$ sodium acetate $\left(\mathrm{NaC}_{2} \mathrm{H}_{3} \mathrm{O}_{2}, \mathrm{pH} 5.2\right)$ and 1.5 volumes of icecold absolute ethanol. Tubes containing samples were inverted several times and incubated at $-20^{\circ} \mathrm{C}$ overnight. Thereafter, the samples were centrifuged at $13000 \times g$ for $10 \mathrm{~min}$, supernatants were carefully discarded and the pellets containing DNA were washed with $70 \%$ ethanol. Finally, samples were centrifuged at $13000 \times g$ for 5 min before decanting the supernatants and air-drying the DNA pellets for a few minutes. DNA was resuspended in $50 \mu \mathrm{l}$ TrisEDTA buffer $(\mathrm{pH}=8.0)$ and stored at $-20^{\circ} \mathrm{C}$ until needed.

Isopropanol method. The isopropanol extraction method reported by Edwards et al. (1991) was used with some minor modifications. To each crude extract ( $\mathrm{n}=6$ ), $150 \mu \mathrm{l}$ of $3 \mathrm{M} \mathrm{NaC}_{2} \mathrm{H}_{3} \mathrm{O}_{2}$ ( $\mathrm{pH}$ 5.2) was added and incubated at $-20^{\circ} \mathrm{C}$ for $15 \mathrm{~min}$. Samples were centrifuged at $13000 \times g$ for $10 \mathrm{~min}$ at $18^{\circ} \mathrm{C}$. The supernatants were carefully transferred to new sterile $1.5 \mathrm{ml}$ microcentrifuge tubes and equal volumes of isopropanol were added. Samples were incubated for $5 \mathrm{~min}$ at room temperature and centrifuged at $13000 \times g$ for $10 \mathrm{~min}$ at $18^{\circ} \mathrm{C}$. Pellets containing DNA were washed with $70 \%$ ethanol and centrifuged at $13000 \times g$ for $5 \mathrm{~min}$. The supernatants were carefully decanted and pellets air-dried for a few minutes before resuspending each DNA pellet in $50 \mu \mathrm{l}$ TrisEDTA buffer $(\mathrm{pH}=8.0)$.

Heat lysis method. To minimize labor-intensive extraction steps, eliminate the use of toxic chemicals such as phenol and chloroform, and facilitate the development of a fast and easy DNA extraction protocol, a simple heat lysis extraction method was tested. This method involved heating crude extracts from mycelia at $95^{\circ} \mathrm{C}$ in the presence of Chelax-100 beads according to the method reported by Macey et al. (2008a) with some minor modifications. This simple heat lysis method has previously been used to isolate total genomic DNA from tissues of numerous marine invertebrates, including oysters and crabs (Macey et al. 2008a,b). Briefly, samples of mycelia that were ground in $300 \mu \mathrm{l}$ of sterile distilled water were transferred to new sterile $1.5 \mathrm{ml}$ microcentrifuge tubes containing $0.04 \pm 0.005 \mathrm{~g}$ Chelax-100 beads (Sodium form, Catalog \#7901). Chelax-100 is comprised of negatively charged microscopic beads that chelate metal ions which are required as catalysts or cofactors in enzymatic reactions. The samples containing Chelax-100 were briefly vortexed and incubated for $20 \mathrm{~min}$ at $56^{\circ} \mathrm{C}$ in a Stuart S1500 orbital incubator set to rotate at $130 \mathrm{rpm}$. This incubation step helps soften membranes and denature enzymes such as DNases. Following incubation, the samples were vortexed briefly before incubating the samples for a further $30 \mathrm{~min}$ at $95^{\circ} \mathrm{C}$ to lyse all of the cells. The lysed samples were allowed to cool rapidly on ice, vortexed briefly and centrifuged at $17000 \times g$ for $5 \mathrm{~min}$ at $4^{\circ} \mathrm{C}$. The resulting supernatants $(\sim 250 \mu \mathrm{l})$ containing genomic DNA were transferred to new $1.5 \mathrm{ml}$ microcentrifuge tubes and stored at $-20^{\circ} \mathrm{C}$ until needed.

\section{DNA sequencing of SSU, LSU and cox2 genes and primer design}

Total genomic DNA from a pure culture of Halioticida noduliformans grown in PYGS broth was extracted using the heat lysis method described above. The small subunit and large subunit ribosomal DNA (SSU and LSU rDNA, respectively) gene regions as well as the mitochondrial DNA (mtDNA) cytochrome oxidase subunit II (cox2) gene region of $H$. noduliformans were selected to design speciesspecific PCR primers. An almost complete sequence of each gene was obtained using PCR with amplification primers SR1 and SR12 (Nakayama et al. 1996) for the SSU rDNA gene, primers LSU-00021F (Sekimoto et al. 2007) and LSU-1170R (Petersen \& Rosendahl 2000) for the LSU rDNA gene, and finally primers COX2-For3 and COX2-Rev3 (Sekimoto et al. 2007) for amplification of the cox2 gene (Table 2). The reaction mixtures (25 $\mu \mathrm{l}$; performed in triplicate) were 
prepared using 5 to 10 ng genomic DNA, $1 \times$ KAPA Taq ReadyMix (Kapa Biosystems; Catalog \#KK1006) and $400 \mathrm{nM}$ of each primer. Amplification was conducted using the Labnet Multigene Thermal Cycler (Labnet International) and consisted of an initial denaturation of $5 \mathrm{~min}$ at $95^{\circ} \mathrm{C}$, followed by 35 cycles at $95^{\circ} \mathrm{C}$ for $1 \mathrm{~min}$, annealing for $1 \mathrm{~min}$, and extension at $72^{\circ} \mathrm{C}$ for $1 \mathrm{~min}$, with a final extension at $72^{\circ} \mathrm{C}$ of $10 \mathrm{~min}$. The optimal annealing temperatures for the different primer pairs are listed in Table 2. The amplified PCR products were analyzed by $0.8 \%$ agarose gel electrophoresis to verify reaction specificity and fragment size before being purified using a PCR purification kit (Roche). The purified PCR products were sequenced using a BigDye Terminator Cycle Sequencing Kit (Applied Biosystems) and ABI3730xl Genetic Analyzer (Applied Biosystems) according to the sequencer manufacturer's instructions. Both forward and reverse primers for each gene were used for cycle sequencing.

Each sequence was edited and assembled using DNAMAN version 4.13 (Lynnon BioSoft). Homology searches were carried out using the basic local alignment search tool (BLASTN) algorithm (Altschul et al. 1990) provided by the Internet service of the National Center for Biotechnology Information (www.ncbi. blast.nlm.nih.gov/BLAST/) to verify reaction specificity. Each gene sequence was then aligned using the optimal alignment option of DNAMAN with gene sequences from other closely related Peronosporomycete species sequences available from GenBank, particularly with organisms within the Halioticida/
Haliphthoros/Halocrusticida clade (accession nos. AB178866, AB285218, AB285222-30), in order to identify conserved regions for designing speciesspecific primers (Sekimoto et al. 2007, Macey et al. 2011). Standard criteria were utilized for primer design (Bustin 2000, 2002, Bustin \& Nolan 2004). Finally, candidate primers were blasted against the GenBank database to ensure specificity during this desktop phase of the study.

\section{Species-specific real-time PCR assay development}

Optimization of real-time PCR cycling conditions

PCR conditions were optimized in order to identify optimal PCR cycling conditions for detection specificity. The PCR reactions were carried out in a volume of $25 \mu \mathrm{l}$ containing 5 to $10 \mathrm{ng}$ of Halioticida noduliformans genomic DNA, $1 \times$ Promega GoTaq ${ }^{\circledR}$ SYBR Green master mix (Promega, Catalog \#A6001) and $400 \mathrm{nM}$ of each primer. Amplification was monitored using a Bio-Rad CFX96 ${ }^{\mathrm{TM}}$ real-time PCR detection system on a C1000 ${ }^{\mathrm{TM}}$ thermal cycler and consisted of an initial denaturation at $95^{\circ} \mathrm{C}$ for $5 \mathrm{~min}$, followed by 35 cycles of denaturation at $95^{\circ} \mathrm{C}$ for $45 \mathrm{~s}$, annealing for $45 \mathrm{~s}$, elongation at $72^{\circ} \mathrm{C}$ for $45 \mathrm{~s}$, 70 cycles of $60^{\circ} \mathrm{C}$ for $10 \mathrm{~s}$ with an increment of $0.5^{\circ} \mathrm{C}$ cycle $^{-1}$. Data collection and real-time analysis occurred at the annealing step of each cycle, and melt curve data collection and analysis occurred at each

Table 2. Universal oligonucleotide primers used to amplify and sequence the small subunit (SSU), large subunit (LSU) and cox2 genes of Halioticida noduliformans and species-specific primers designed and tested for real-time quantitative PCR assay development in this study. Optimal annealing temperatures and product sizes are listed beside each primer set

\begin{tabular}{|c|c|c|c|c|c|c|}
\hline $\begin{array}{l}\text { Set } \\
\text { no. }\end{array}$ & Primer name & Sequence $\left(5^{\prime}-3^{\prime}\right)$ & $\begin{array}{l}\text { Target } \\
\text { region }\end{array}$ & $\begin{array}{c}\text { Product } \\
\text { size } \\
\text { (bp) }\end{array}$ & $\begin{array}{c}\text { Annealing } \\
\text { tempera- } \\
\text { ture }\left({ }^{\circ} \mathrm{C}\right)\end{array}$ & Source \\
\hline \multicolumn{7}{|c|}{ Universal fungal } \\
\hline \multirow[t]{2}{*}{1} & SR1-F & TACCTGGTTGATCCTGCCAG & SSU rDNA & 1781 & 55 & Nakayama et al. (1996) \\
\hline & SR12-R & CCTTCCGCAGGTYTCACCTAC & SSU rDNA & & & Nakayama et al. (1996) \\
\hline \multirow[t]{2}{*}{2} & LSU-00021F & ATTACCCGCTGAACTTAAGC & LSU rDNA & 1170 & 63 & Sekimoto et al. (2007) \\
\hline & LSU-1170R & GCTATCCTGAGGGAAATTTCGG & LSU rDNA & & & Petersen \& Rosendahl (2000) \\
\hline \multirow[t]{2}{*}{3} & COX2-For3 & GCHACHCCWGTWATGGARGG & $\operatorname{cox} 2$ & 540 & 40 & Sekimoto et al. (2007) \\
\hline & COX2-Rev3 & TACATTGDCCRTAAAAAAYMCC & $\operatorname{cox} 2$ & & & Sekimoto et al. (2007) \\
\hline \multicolumn{7}{|c|}{ Species-specific } \\
\hline \multirow[t]{2}{*}{4} & HN.SSU-F & GCTCATTATATCAGTTATAGTCT & SSU rDNA & 174 & 52 & This study \\
\hline & HN.SSU-R & CCGCACAGTTATTATGAC & SSU rDNA & & & This study \\
\hline \multirow[t]{2}{*}{5} & HN.LSU-F & CGTCATAGTCAGTTTGTAT & LSU rDNA & 141 & 59 & This study \\
\hline & HN.LSU-R & ATCCCATCAATACCCTTA & LSU rDNA & & & This study \\
\hline \multirow[t]{2}{*}{6} & HN.COX2-F & GTTATATGGTTCAAGAAGAT & $\operatorname{cox} 2$ & 177 & 55 & This study \\
\hline & HN.COX2-R & ACATAGAGGTTTGGTTTA & $\operatorname{cox} 2$ & & & This study \\
\hline
\end{tabular}


increment in the latter 70 cycles. To determine the conditions giving the highest specificity we varied the annealing temperatures and the PCR cycle numbers for each primer set.

Specificity of the SSU, LSU and cox2 gene primer sets

Primer pairs for the SSU, LSU and cox2 genes were tested for cross-reactivity to DNA extracted from cultured hyphae of other closely related Peronosporomycete species as well as from marine fungi isolated from the environment. The environmental samples included fungi isolated from abalone, seaweeds and crustaceans (Table 1). DNA (5 to $10 \mathrm{ng}$ ) from each sample, extracted using the heat lysis method, was added to the PCR mixtures and amplified as described above. The optimal annealing temperatures for the different primer pairs are listed in Table 2 . Each PCR assay included a positive control that consisted of Halioticida noduliformans genomic DNA in the reaction mixture and a negative control (NTC) that substituted PCR-grade water for DNA to confirm that the reagents were not contaminated. A PCR with amplification primers SR1 and SR12 for the SSU rDNA gene was included as an additional positive control to determine the quality and integrity of genomic DNA isolated from each of the tested fungal species. PCR products were analyzed by agarose gel electrophoresis to verify reaction specificity and fragment size, and all amplified products of the correct size (Table 2) were sequenced to further confirm reaction specificity.

\section{Sensitivity of the $H$. noduliformans-specific LSU primer set}

Halioticida noduliformans-specific primers HN. LSU-F and HN.LSU-R were chosen for all subsequent experiments (Table 2). The lowest detection limit for this primer set was evaluated by running real-time qPCRs on serial dilutions of known quantities of extracted $H$. noduliformans DNA. Serial dilutions were made in PCR-grade water (in vitro study) as well as in an abalone tissue matrix (seeded study). The abalone tissue matrix consisted of supernatant obtained following genomic DNA extraction from abalone tissue using the heat lysis method described above (see 'Heat lysis method'). This seeded study served to further validate specificity and quantify the amount of PCR inhibition and the lowest detection limit for the $H$. noduliformans-specific primer set in an environment or matrix that is designed to be a non-sterile simulation of the environmental conditions. DNA added for sensitivity testing ranged from 2800 to $0.028 \mathrm{pg}$. The real-time PCR cycling conditions were as described above (see 'Optimization of real-time PCR cycling conditions') for the $H$. noduliformans LSU-specific primers HN.LSU-F and HN.LSU-R. The optimal annealing temperatures for this primer pair are listed in Table 2 .

To further confirm the specificity and sensitivity of the Halioticida noduliformans-specific primer set, real-time PCR assays were performed on DNA extracted from experimentally and naturally infected abalone. Healthy abalone were experimentally infected with laboratory grown cultures of $H$. noduliformans according to the method described by Macey et al. (2011). This 'incurred study' as well as the analysis of naturally infected abalone served to establish the possible impact of physiological changes in $H$. noduliformans cells, resulting from adaptation, growth and spread within the host, on the performance of the real-time PCR technique. In both cases, small pieces of affected tissue (necrotic regions $<2 \mathrm{~mm}^{3}$ ) on the epipodium and foot muscle were carefully excised from Haliotis midae exhibiting typical clinical lesions of tubercle mycosis (Macey et al. 2011) and processed for heat lysis genomic DNA extraction as previously described. Aliquots of tissue from known Halioticida noduliformans-negative abalone, along with non-template controls (PCR-grade $\mathrm{H}_{2} \mathrm{O}$ ), were analyzed as negative controls to ensure that there was no amplification except for the $H$. noduliformans DNA. In addition, 3 separate aliquots $(300 \mu \mathrm{l})$ of PCR-grade water were spiked with a known concentration of $H$. noduliformans DNA (28000 pg DNA, final concentration) and subjected to the heat lysis DNA extraction to quantify the potential loss of DNA during the extraction process.

To prepare abalone tissue for heat lysis genomic DNA extraction, foot muscle and/or epipodial tissue $(0.2$ to $0.3 \mathrm{~g})$ was aseptically transferred to a sterile $15 \mathrm{ml}$ centrifuge tube containing $2 \mathrm{ml}$ phosphate buffered saline (PBS; $7.3 \mathrm{mM}$ monosodium phosphate, $180 \mathrm{mM}$ disodium phosphate, $0.15 \mathrm{M}$ sodium chloride, pH 7.2), supplemented with 0.05\% Antifoam A and $0.1 \%$ Tween 20 . The sample was homogenized for 1.5 min using a Polytron PT 2100 tissue homogenizer, and $300 \mu \mathrm{l}$ aliquots of homogenate were transferred to separate $1.5 \mathrm{ml}$ microcentrifuge tubes. Tubes containing homogenized abalone tissue were stored on ice for immediate use or at $-80^{\circ} \mathrm{C}$ 
until needed. Tissue samples for real-time PCR were centrifuged at $17000 \times g$ for $10 \mathrm{~min}$ at $4^{\circ} \mathrm{C}$. The resulting supernatants were removed and the pellets resuspended in an equal volume $(300 \mu \mathrm{l})$ of sterile distilled water. Genomic DNA was then extracted from abalone tissue using the heat lysis method described above (see 'Heat lysis method').

Serial dilutions of known quantities of extracted Halioticida noduliformans DNA prepared in PCRgrade water served as a standard curve for the quantification of DNA spiked into the abalone tissue matrix. Thereafter, serial dilutions of known quantities of extracted $H$. noduliformans DNA prepared in the abalone tissue matrix served as a standard curve, allowing us to quantify the amount of $H$. noduliformans DNA in tissues of experimentally and naturally infected abalone. An estimation of $H$. noduliformans spore number in spiked abalone tissues and experimentally and naturally infected abalone tissues was calculated according to Hermansson \& Lindgren (2001) and based on the following 4 assumptions. (1) The genome size of $H$. noduliformans is $108 \mathrm{Mbp}$. This estimate is based on an average of the genome sizes published for the plant pathogens Hyaloperonospora parasitica (75 Mbp), Phytophthora capsica (65 Mbp), P. infestans (240 Mbp), P. ramorum (65 Mbp), and P. sojae (95 Mbp) (Lamour et al. 2007). (2) There is only one genome per spore. (3) One kb of double-stranded (dsDNA) is approximately equal to $0.662 \times 10^{6} \mathrm{Da}$ (Coyne et al. 1996). (4) One Da is equal to $1.67 \times 10^{-24} \mathrm{~g}$ (Garret \& Grisham 1995). The amount of DNA quantified in spiked abalone tissue and in experimentally and naturally infected abalone tissues by real-time PCR was then divided by the estimated amount of DNA per cell $\left(\sim 1.122 \times 10^{-7} \mu \mathrm{g}\right.$ DNA) to estimate the total number of spore equivalents recovered from abalone tissue.

\section{Statistical analysis}

SigmaStat 3.1 software was used to perform all statistical analyses. To determine whether the yield of DNA per mg hyphae differed between samples physically disrupted using fine bead homogenization, grinding with a conical grinder, and liquid nitrogen freezing followed by grinding with a conical grinder, a 1-way analysis of variance (ANOVA) was performed. Tests for equal variance failed for these data sets; therefore, a Kruskal-Wallis 1-way ANOVA on ranks was used to test for significant differences. A Tukey's test was used for post hoc multiple comparisons between treatments. Similarly, a 1-way
ANOVA was performed to test for significant differences in the yield of DNA between the isopropanol, phenol-chloroform and heat lysis extraction methods. The Holm-Sidak method was used for post hoc multiple comparisons between extraction methods. Significance was assigned to $p$-values $<0.05$ for 1 -way ANOVAs, Tukey's and Holm-Sidak analyses.

\section{RESULTS}

\section{DNA extractions}

Fungal cell-wall disruption

Fungal cell-wall disruption and lysis was visually assessed following each physical disruption method and compared to untreated cultures as controls, using a light microscope. The degree of cell lysis was assessed on a scale of 0 to $100 \%$ and complete lysis of cells was defined as empty cells that were completely broken and devoid of all cellular contents. Minimal to no lysis of cells was observed following physical disruption with glass beads (Fig. 1A). Conversely, mycelia that were ground with a conical grinder immediately after being flash-frozen in liquid nitrogen showed a higher degree of cell lysis, with $50 \%$ of the cells exhibiting some lysis (25-50\% lysis) and $16 \%$ of cells exhibiting almost complete lysis (75$100 \%$ lysis; Fig. 1A). However, upon microscopic examination, cells physically disrupted using the conical grinder method without liquid nitrogen showed the highest degree of cell lysis, with almost complete lysis observed in more than $66 \%$ of the samples (Fig. 1A). The yield of DNA obtained from the latter samples was also significantly higher (Kruskal-Wallis 1-way ANOVA on ranks; $\mathrm{p}<0.05$ ), when compared to the glass bead method (Fig. 1B). DNA yield following disruption using the conical grinder method ranged from 0.25 to $2.7 \mu \mathrm{g}$ DNA per mg starting hyphae mass (wet wt). There was no significant difference $(p>0.05)$ in the yield of DNA between samples physically disrupted using the conical grinder method with or without the liquid nitrogen pre-treatment and as a consequence the conical grinder method was selected as the most efficient physical disruption method for all subsequent optimizations.

\section{Enzymatic digestion}

In an effort to further improve the yield of DNA obtained from samples physically disrupted 


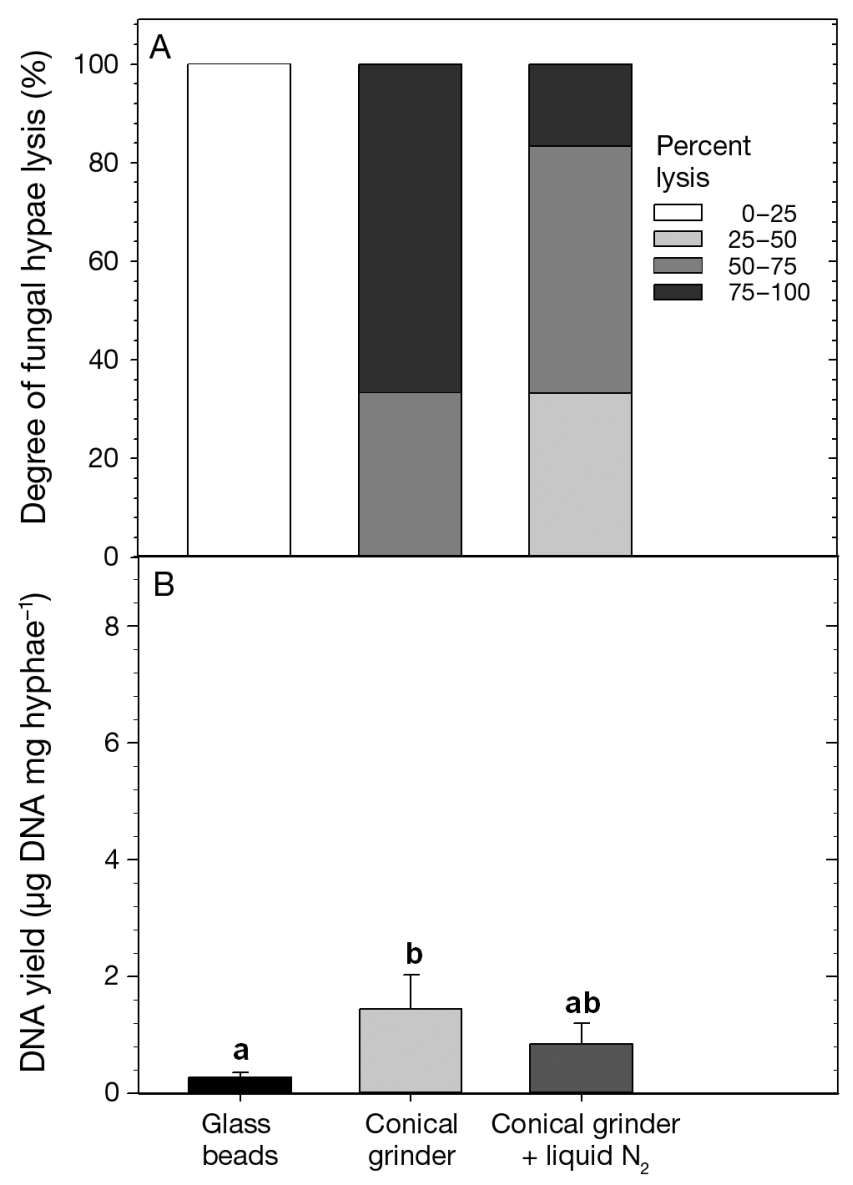

Fig. 1. Three methods used to physically disrupt mycelium cell walls: fine bead homogenization, grinding with a conical grinder, and liquid nitrogen freezing followed by grinding with a conical grinder. (A) The degree of cell wall lysis was subjectively assessed and categorized according to Karakousis et al. (2006) by observing mycelia from each sample under a light microscope and comparing to untreated cultures as controls and expressed as percentages falling within the following categories: (1) for samples with no to minimal $(0-25 \%)$ cell lysis, (2) if some breakage of mycelia (25-50\%) was observed in the sample, (3) if most of the hyphae (50-75\%) were lysed, and finally (4) if almost complete cell wall breakage (75-100\%) was observed in the sample. (B) The mean $( \pm \mathrm{SE})$ yield of genomic DNA obtained from $1 \mathrm{mg}$ of mycelia following each mechanical disruption method. Different letters indicate significant differences. A total of 6 samples were tested for each physical disruption method

using the conical grinder method, fungal material was digested with 2 commonly used cell-wall degrading enzymes, namely lyticase and Proteinase K, and compared with untreated controls. DNA yield varied significantly across treatment groups (1-way ANOVA $_{i} \mathrm{p}=0.023$ ) and fungal material digested with Proteinase $\mathrm{K}$ yielded significantly higher amounts (1-way ANOVA; $\mathrm{p}=0.009$ ) of DNA com- pared with fungi digested with lyticase (Fig. 2). There was however no significant difference in the yield of DNA between the treatment groups and the control. Consequently, enzymatic digestion was omitted from all subsequent extractions.

\section{Fungal DNA extraction and recovery}

Following physical disruption of cells with a conical grinder, 2 routine DNA extraction and recovery methods, namely isopropanol and phenolchloroform, were tested and compared to a simple heat lysis method. The heat lysis method has previously been reported to be an efficient method for extracting and recovering DNA from a diverse range of marine invertebrates (Burgents et al. 2005, Macey et al. 2008a,b). Our results confirmed these reports and showed that the modified heat lysis method tested in this study yielded significantly higher quantities of high quality DNA compared with the phenol-chloroform and isopropanol methods ( $p=0.0049$ and 0.0055 , respectively) (Fig. 3). In fact, the average yield of DNA obtained using the heat lysis method was $7.2 \mu \mathrm{g}$ DNA per $\mathrm{mg}$ of hyphae, which is more than twice the amount of DNA recovered using the 2 other tested DNA extraction and recovery methods. As a result, heat lysis was selected as the most efficient method for extracting and recovering DNA from fungal cells physically disrupted using the conical grinder method.

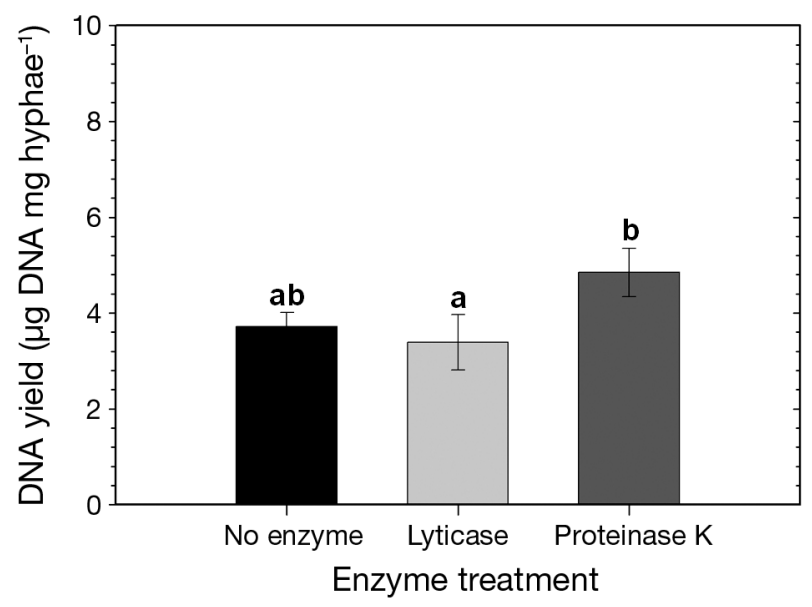

Fig. 2. Mean yield $\left( \pm S E_{;} n=10\right)$ of DNA obtained from $1 \mathrm{mg}$ of mycelia physically disrupted using a conical grinder and then digested with either lyticase or Proteinase-K and compared with untreated controls. Different letters indicate significant differences 


\section{Species-specific real-time PCR assay development}

Specificity of SSU, LSU and cox2 gene primer sets and optimization of real-time PCR cycling conditions

Identification of a suitable DNA target region and the development of PCR primers specific to a target organism are 2 of the most important steps in PCR diagnostics. Primer pairs HN.LSU-F/R and HN.COX2-F/R (Table 2), targeting the LSU rDNA and mtDNA cox2 gene regions, respectively, were found to be highly specific when tested against a panel of closely related Peronosporomycete species as well as fungi isolated from the marine environment (Fig. 4). Both of these primer sets showed no cross-reactivity with the closely related fungi tested in this study and only amplified DNA from Halioticida noduliformans at the specified annealing temperatures (Table 2, Fig. 4). The amplified DNA was also sequenced to confirm the specificity of the PCR reactions and subsequent analysis of the nucleotide sequences showed that the PCR products, approximately $140 \mathrm{bp}$ in length, were identical to $H$. noduliformans. In contrast, the HN. SSU-F/R primer pair cross-reacted with all tested fungi. Thus, HN.LSU-F/R and HN.COX2-F/R both appeared to be good candidates for a $H$. noduliformans-specific primer pair. However, due to the availability of larger amounts of sequence information for the LSU gene for Peronosporomycete species, the utilization of more stringent criteria (avoiding template structure and cross homology) is needed in the design of the LSU primer pair, and since ribosomal RNA genes are highly abundant in fungal cells, having between 100 and 200 copies per cell (Zhou et al. 2000), the HN.LSU-F/R primer set was assumed to be the most sensitive and it was subsequently chosen for further investigation.

Real-time PCR conditions were optimized in order to identify optimal PCR cycling conditions for detection specificity by varying the annealing temperatures for the HN.LSU-F/R primer set and the number of PCR cycles. The optimal annealing temperature was determined to be $59^{\circ} \mathrm{C}$, with a melting temperature of $79 \pm 1{ }^{\circ} \mathrm{C}$ for the $141 \mathrm{bp}$ PCR product (Table 2). Any samples that recorded a quantification cycle (Cq) value on the amplification graph after setting the PCR cycle number and baseline threshold values to 35 and 300, respectively, and had a melt peak of $79 \pm 1^{\circ} \mathrm{C}$ on the melt curve graph were considered to be positive. Samples that failed to record a Cq value or failed to produce a specific melt peak were considered to be negative. Under these conditions, no amplification of closely related

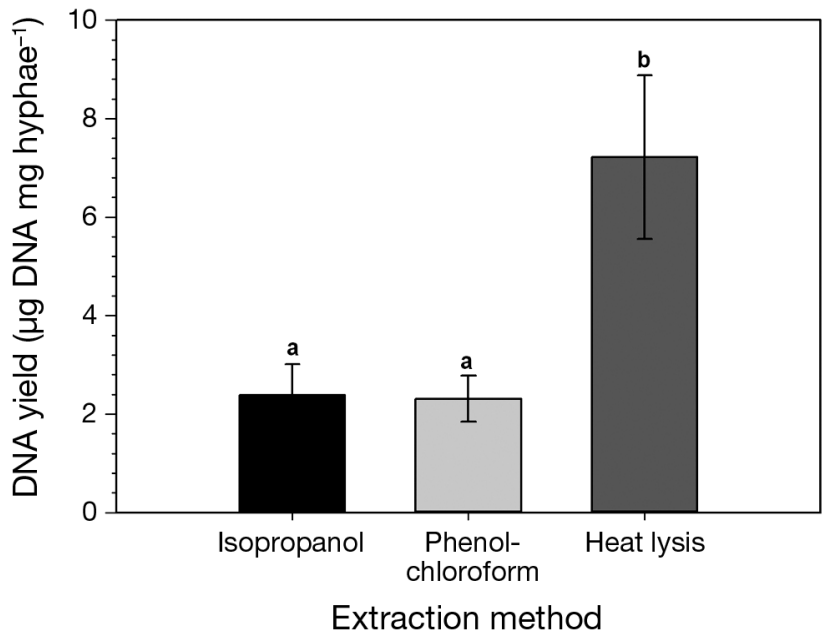

Fig. 3. Mean yield $( \pm \mathrm{SE} ; \mathrm{n}=6$ ) of DNA extracted and recovered from $1 \mathrm{mg}$ of mycelia using the isopropanol, phenolchloroform or heat lysis methods. All samples were physically disrupted using the conical grinder method prior to DNA extraction and precipitation. Different letters represent a significant difference ( $\mathrm{p}<0.05$; 1 -way ANOVA) between treatments

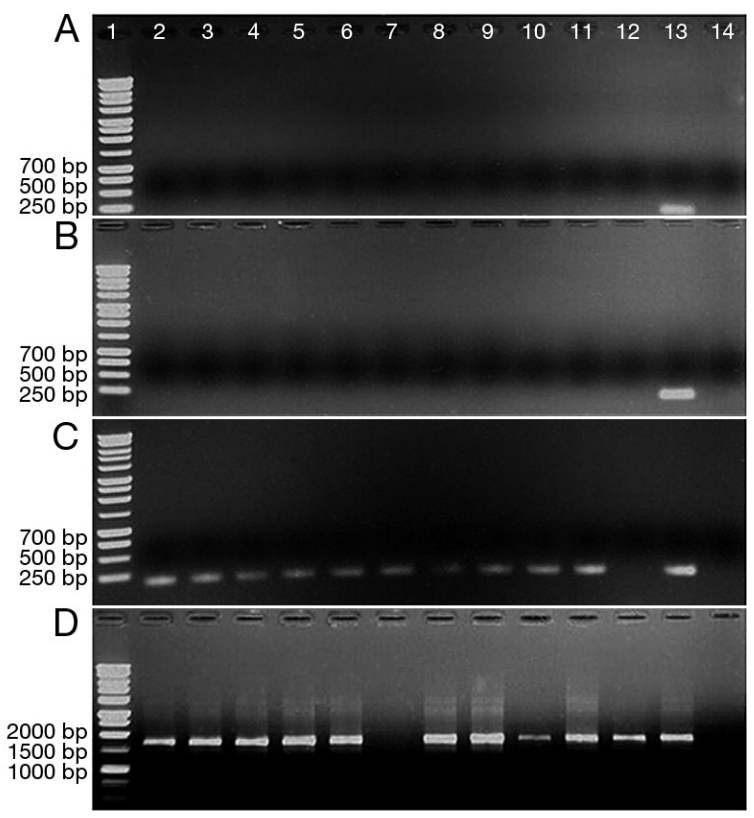

Fig. 4. (A) Large subunit (LSU) ribosomal RNA, (B) mitochondrial DNA cytochrome oxidase subunit II (cox2), and (C) small subunit (SSU) ribosomal RNA primer sets specific to Halioticida noduliformans were tested for cross-reactivity with genomic DNA isolated from closely related Peronosporomycetes and marine fungi isolated from the immediate environment. (D) PCR of genomic DNA using a universal fungal LSU primer set (positive control). Lane 1: $1 \mathrm{~kb}$ ladder; Lane 2: Pleosporales sp., Lane 3: Isaria tenuipes; Lane 4: Hypocreales sp. (isolate A); Lane 5; Fusarium sp.; Lane 6: Microascus sp.; Lane 7: Hypocreales sp. (isolate B); Lane 8: Hypocreales sp. (isolate C); Lane 9: Stanjemoniom sp.; Lane 10: Unknown A; Lane 11: Unknown B; Lane 12: Aphanomyces astaci; Lane 13: Halioticida noduliformans; Lane 14: non-template control (NTC) 
Peronosporomycete or environmental fungi DNA was recorded.

\section{Sensitivity of the $H$. noduliformans-specific LSU primer set}

Quantitative, sensitive and specific detection of Halioticida noduliformans DNA from pure cultures and spiked, experimentally and naturally infected abalone tissues is of critical importance to guarantee the biological significance of the real-time PCR results. Real-time quantitative PCR on serial dilutions of known quantities of extracted $H$. noduliformans DNA made in PCR-grade water revealed that the lowest detection limit for the HN.LSU-F/R primer set is approximately $0.28 \mathrm{pg}$ of DNA in a $25 \mu \mathrm{l}$ reaction volume (Fig. 5). Even though amplification occurred with $0.028 \mathrm{pg}$ of DNA present in the reaction mixture, only 1 out of the 3 replicate samples was positive in this case. The Cq value was also very high in this PCR reaction ( $>34$ cycles), indicative of low sensitivity. Based on the assumption that $1 \mathrm{H}$. noduliformans spore contains $1.22 \times 10^{-7} \mu \mathrm{g}$ DNA, we calculated the lowest detection limit for the in vitro realtime PCR to be approximately 2.3 spores or spore equivalents in a $25 \mu \mathrm{l}$ reaction volume.

In order to quantify the amount of PCR inhibition and the lowest detection limit for the LSU-specific primer set under environmental conditions (seeded study), real-time qPCR reactions on serial dilutions of known quantities of extracted Halioticida noduliformans DNA were carried out in an abalone tissue matrix and compared with equivalent dilutions made in PCR-grade water. Our results demonstrated a minimal overall reduction in real-time PCR sensitivity $(<2 \%)$, as indicated by the slight increase in PCR cycle number at each corresponding DNA concen-

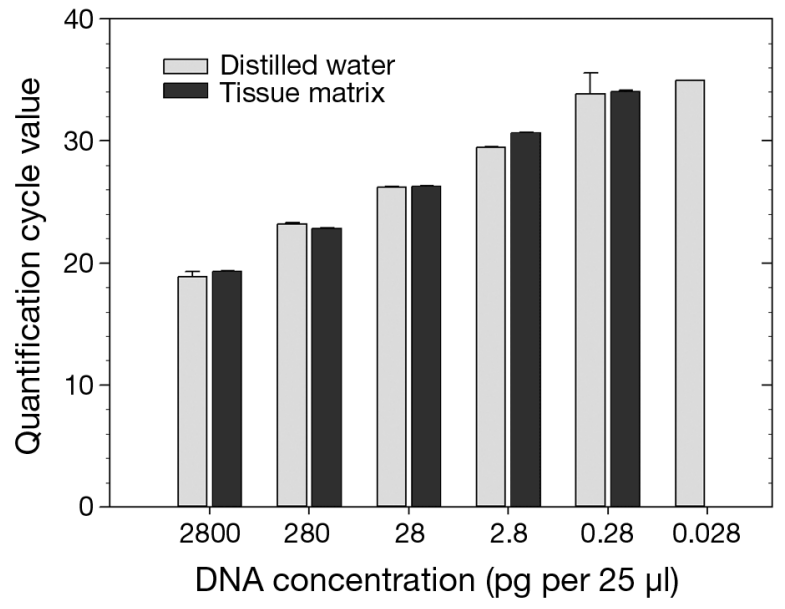

Fig. 5. Quantification cycle (Cq) threshold values obtained following real-time PCR on serial dilutions of known quantities of extracted Halioticida noduliformans DNA made in PCR-grade water and in an abalone tissue matrix. This seeded study served to quantify the amount of PCR inhibition and the lowest detection limit for the $H$. noduliformansspecific primer set in an environment or matrix that is designed to be a non-sterile simulation of the environmental conditions

tration (Fig. 5). The lower detection limit for the real-time PCR assay within an abalone tissue matrix remained around $0.28 \mathrm{pg}$ of fungal DNA ( 2.3 spores) in a $25 \mu \mathrm{l}$ reaction volume. We further demonstrated that the real-time PCR assay developed in this study is capable of detecting $H$. noduliformans in both experimentally infected and naturally infected abalone tissues (Table 3). The estimated spore number for experimentally infected abalone was determined to be 173 spores per $25 \mu \mathrm{l}$ reaction volume and ranged from 5 to 58 spores per $25 \mathrm{\mu l}$ reaction volume for naturally infected abalone. The mean concentration of $H$. noduliformans DNA recovered from distilled water following heat lysis

Table 3. Real-time PCR specificity and sensitivity results (mean \pm SE) following amplification with the Halioticida noduliformans-specific primers HN.LSU-F and HN.LSU-R. Samples included both naturally and experimentally infected abalone exhibiting typical clinical lesions of tubercle mycosis, healthy abalone tissues (negative controls) and spiked healthy abalone tissue and water samples. Cq: quantification value

\begin{tabular}{|lcrr|}
\hline Sample description & Cq value & $\begin{array}{c}\text { Calculated DNA } \\
\text { Conc. (pg per 25 } \mu \text { l) }\end{array}$ & $\begin{array}{c}\text { Estimated no. } \\
\text { of spores }\end{array}$ \\
\hline Naturally infected abalone tissue (a) & $33.28 \pm 1.14$ & $0.65 \pm 0.28$ & 5.34 \\
Naturally infected abalone tissue (b) & $28.85 \pm 0.14$ & $7.07 \pm 0.59$ & 57.93 \\
Experimentally infected abalone tissue & $27.36 \pm 0.66$ & $21.15 \pm 9.26$ & 173.40 \\
Healthy tissue spiked with H. noduliformans hyphae & $25.41 \pm 0.49$ & $61.86 \pm 15.10$ & 507.06 \\
Distilled water spiked with H. noduliformans DNA & $15.56 \pm 0.08$ & $26298.98 \pm 1294.85$ & 215565.48 \\
Healthy abalone tissue (Negative control) & 0 & 0 & 0 \\
Non-template control (NTC) & 0 & 0 & 0 \\
\hline
\end{tabular}


extraction was $26298 \mathrm{pg}$ ( $94 \%$ recovery), suggesting minimal loss of DNA following heat lysis extraction. Furthermore, the lack of PCR amplification from the non-template controls as well as from tissues obtained from healthy abalone (negative controls) further confirms the specificity of the $H$. noduliformans LSU primers HN.LSU-F and HN.LSU-R.

\section{DISCUSSION}

Abalone tubercle mycosis is an epizootic of farmed abalone that is caused by infection by the invasive Peronosporomycete Halioticida noduliformans. It has an infectious aetiology and has been regarded by South African regulatory authorities as a disease that is contagious, and may pose an economic risk to the industry or pose significant risks to the already vulnerable wild abalone populations. Rapid specific identification of the fungus responsible for abalone tubercle mycosis is therefore of utmost importance for effective management and containment of this pathogen. This study describes the development of a simple heat lysis method for extraction and recovery of DNA suitable for sensitive and precise quantification by PCR and the subsequent development and validation of a real-time PCR assay for rapid detection and quantification of $H$. noduliformans from infected abalone tissues. The specificity of the realtime qPCR assay was tested against a panel of closely related Peronosporomycetes as well as fungi isolated from the immediate environment, and no false positive results due to cross-amplifications were observed when using the HN.LSU-F/R primer set. When performing real-time PCR assays in an environment or matrix that is designed to be a non-sterile simulation of the environmental conditions, no amplification occurred in the negative controls that substituted PCR-grade water for DNA and the sensitivity of the qPCR assay was determined to be at least $0.28 \mathrm{pg}$ of fungal DNA, approximately 2.3 spores, in a $25 \mu \mathrm{l}$ reaction volume. Moreover, we have repeatedly demonstrated that no amplification occurs in samples obtained from healthy abalone and the realtime PCR assay can specifically detect $H$. noduliformans in both experimentally and naturally infected abalone. This study describes the first real-time qPCR assay capable of specifically and sensitively detecting $H$. noduliformans in abalone tissues.

To ensure sensitive and precise quantification by qPCR and hence the biological relevance of the molecular diagnostic tool developed in the current study, the recovery of high quality DNA needed to be maxi- mized. Unlike animal and bacterial cells, fungal cell walls are extremely tough and are often hard to disrupt by commonly used cell lysis methods, such as chemical and enzymatic digestion (Zhou et al. 2000). However, physical disruption methods using glass or zirconia beads, freeze/thaw and a freeze press have been shown to be rapid, effective and convenient methods for disrupting cells and releasing DNA from fungi (Zhou et al. 2000, Wu et al. 2002). Karakousis et al. (2006) also demonstrated that pestle grinding was an efficient method for lysing fungal hyphae. In the present study, we demonstrated that homogenization using a motorized pellet pestle was more efficient at physically disrupting fungal cell walls than homogenization with glass beads. Furthermore, we demonstrated that freezing of cells in liquid nitrogen prior to pellet pestle grinding did not significantly improve the efficacy of lysis or the yield of DNA. Glass and zirconia beads have both been shown to be highly efficient methods for fungal cell disruption, but the efficacy of these 2 methods is dependent on the fungal species or stage of fungal development as well as the type of instrument used, as pulsing vortex mixers, for example, have been shown to be less effective at disrupting fungal cell walls when compared with a bead beater (Zhou et al. 2000, Yamamoto et al. 2010). As a consequence, a lot of trial and error is required in order to select the correct bead and instrument type for optimal cell lysis and these optimized methods may then also differ from species to species. In contrast, the conical grinder method developed in this study has been tested on several species of fungi (Table 1) and has been shown to be a simple, cheap, rapid, and highly efficient method for lysing cell walls.

Co-purification of contaminants from environmental and animal tissue samples that could inhibit PCR and potentially cause false-negative results requires careful consideration for the design of all PCR-based procedures (Bott et al. 2010). Inhibitors may include organic and phenolic compounds; metal ions; $\mathrm{Ca}^{2+}$, $\mathrm{Mg}^{2+}, \mathrm{Na}^{2+}$ and other salts that are in high abundance in marine samples; constituents of microbial and fungal cells; an over-abundance of non-target DNA; and other contaminants (Bott et al. 2010, Yamamoto et al. 2010). Therefore, DNA extraction and recovery methods need to be thoroughly assessed and optimized to not only enhance recovery of DNA but also reduce the presence of PCR inhibitors. Boiling mycelia and tissue samples to obtain template DNA suitable for PCR is not uncommon, but sensitive and reproducible detection of pathogens within these samples does require DNA extraction procedures that will eliminate 
PCR inhibitors (Ma \& Michailides 2007). Dilution of DNA extracts has been shown to curtail the effects of PCR inhibitors, but this also causes a reduction in PCR efficacy (Ma \& Michailides 2007). We demonstrated that physical disruption using a conical grinder followed by heat lysis of mycelia in the presence of Chelax-100 beads was highly effective at disrupting cells and yielding high quality DNA with minimal PCR inhibition. Organic extraction methods, such as phenol-chloroform and isopropanol, are routinely and successfully used for the extraction and recovery of DNA, however these methods require toxic chemicals and involve one or more phase extractions that may lead to loss of DNA. In contrast, the supernatants in the present study were used directly for PCR following heat lysis, eliminating DNA purification and precipitation steps and resulting in minimal $(<6 \%)$ loss of DNA, thus making this method more convenient and practical for real-time PCR and as a diagnostic tool. Similar methodologies have been successfully used for direct quantification of Vibrio campbellii cells in tissues of the Atlantic blue crab Callinectes sapidus (Macey et al. 2008b) and eastern oyster Crassostrea virginica (Macey et al. 2008a) and to quantify the gene expression of lysozyme (Burge et al. 2007) and peroxinectin (Burge et al. 2009) in the Pacific white shrimp Litopenaeus vannamei in response to a pathogen challenge. Collectively, these studies demonstrate the relevance, convenience and effectiveness of a simple heat lysis method for the extraction and recovery of DNA suitable for real-time qPCR.

Specific identification of Halioticida noduliformans is critical for early diagnosis of abalone tubercle mycosis and for effective management and containment of this pathogen. We selected the LSU rRNA gene region to design species-specific PCR primers for $H$. noduliformans since these genes are highly abundant within the eukaryotic cell and contain numerous variable regions for distinguishing among closely related taxa (Li et al. 1996). A BLAST search of the GeneBank database revealed that both forward and reverse primers targeting the $H$. noduliformans LSU rRNA gene differed by at least 2 nucleotides from all known rRNA gene sequences, demonstrating the specificity of this primer set. We further demonstrated that the designed HN.LSU-F/R primer pair did not cross-react with any of the closely related fungi tested in this study and only amplified DNA from $H$. noduliformans at the specified annealing temperature. Specificity was further confirmed by the specific amplification of $H$. noduliformans DNA from experimentally and naturally infected abalone tissue samples and by the lack of amplification from healthy abalone tissue samples. These results provide sound presumptive evidence for the specificity of the LSU primer set for $H$. noduliformans and confirmed previous studies that have demonstrated that oligonucleotide probes with as little as a single nucleotide mismatch to the target sequence can differentiate between closely related species ( $\mathrm{Li}$ et al. 1996).

Once specificity was confirmed, purified fungal DNA was spiked into an abalone tissue matrix to evaluate the lower detection limit of the LSU primer set for Halioticida noduliformans within a representative non-sterile matrix. This aspect of PCR assay development is essential as it allows one to evaluate the impact of the physical and chemical properties of the matrices themselves on the performance and overall dynamics of a PCR assay (Hiney \& Smith 1998). Zhou et al. (2000) stated that the average lower detection limits of fungal DNA reported in the literature range from 0.1 to $1 \mathrm{pg}$ fungal DNA per reaction, whereas other studies have reported even lower limits of detection (Oidtmann et al. 2004, Phadee et al. 2004). However, almost all of these studies were performed in a traditional 'test-tube' or non-seeded matrix using serially diluted purified fungal DNA. For example, Phadee et al. (2004) developed a PCR assay to detect Aphanomyces piscicida in experimentally infected gold fish Carassius auratus and estimated a lower limit of detection for the assay of approximately $0.5 \mathrm{pg}$ DNA per reaction. Likewise, Oidtmann et al. (2004) developed a PCR assay to detect infection of crayfish with $A$. astaci and reported a detection threshold of at least $0.1 \mathrm{pg}$ of DNA after 30 PCR cycles. The latter authors also reported that $A$. astaci could be detected in cuticle samples even before visible hyphae-like structures could be identified, suggesting that their PCR assay was highly sensitive (Oidtmann et al. 2004). Unlike these previous studies, our study has directly accounted for potential inhibitors present in tissue samples and the subsequent possibility of false-positive and -negative results. Using an abalone tissue matrix spiked with $H$. noduliformans DNA and a real-time qPCR approach, we demonstrated a potential lower detection limit of approximately $0.28 \mathrm{pg}$ of fungal DNA ( 2.3 spores $)$ in a $25 \mu$ reaction volume.

Unlike seeded matrices, which are limited to providing information on how the physical and chemical properties of a matrix may affect the basic properties of a technique such as PCR, non-seeded or incurred studies utilizing experimentally infected animal tissues and tissues from naturally infected animals provide additional information on the potential phys- 
iological adaptations incurred by cells via their interaction with the host organism (Hiney \& Smith 1998). Nutrient limitations characteristically encountered in host tissues and interactions with the host immune system may induce significant physiological changes in the target cell and increase the number of viable, but non-culturable, cells within the host. Collectively, these factors may lead to a reduction in DNA content of the target cell (to as little as 5 to $10 \%$ of the original amount), reduce DNA extraction efficiency and yield DNA that is less amenable to PCR amplification (Hiney \& Smith 1998). As a consequence, seeded matrices alone cannot be used for the validation of diagnostics techniques, but should be supplemented by incurred studies for assessing the overall performance of a technique. In this study, we demonstrated that the Halioticida noduliformans LSU primer set can specifically amplify $H$. noduliformans DNA from both seeded and incurred matrices as well as from naturally infected animal tissues. However, for both incurred studies and natural infections, tissue samples were obtained from abalone exhibiting typical clinical lesions of tubercle mycosis (Macey et al. 2011). Additional studies are therefore needed to determine the distribution of $H$. noduliformans in infected abalone and whether this technique is sensitive enough for the diagnosis of abalone tubercle mycosis in sub-clinically infected animals.

In conclusion, we have developed a molecular technique for rapid specific identification and quantification of Halioticida noduliformans in abalone tissues. Homogenization and lysis techniques have been developed and optimized to maximize DNA yields and provide DNA that is suitable for sensitive and precise quantification of $H$. noduliformans by real-time PCR. Unlike current methods of diagnosis for abalone tubercle mycosis, such as histopathology and gross observation, this technique can be performed in a relatively short period of time (within a few hours) and allows for unambiguous identification of $H$. noduliformans. Even though the molecular technique developed in this study was found to be practical, specific, and sensitive, ongoing research to further improve the practicality and sensitivity of diagnosis for abalone tubercle mycosis is still underway. Collectively, the information generated from the current and ongoing research will assist resource managers and farmers to better predict when an outbreak of abalone tubercle mycosis may occur and consequently further contribute to the prevention, emergence, establishment and spread of abalone tubercle mycosis in the South African abalone aquaculture industry and elsewhere.
Acknowledgements. This report is based upon work supported by the Marine Living Resources Fund through the Department of Agriculture, Forestry and Fisheries. We thank B. Oidtmann (Cefas, UK) for the provision of the Aphanomyces astaci samples (FDL 457) used in this analysis.

\section{LITERATURE CITED}

Altschul SF, Gish W, Miller W, Myers EW, Lipman DJ (1990) Basic local alignment search tool. J Mol Biol 215:403-410

> Bolton JJ, Robertson-Andersson DV, Shuuluka D, Kandjengo L (2009) Growing Ulva (Chlorophyta) in integrated systems as a commercial crop for abalone feed in South Africa: a SWOT analysis. J Appl Phycol 21:575-583

Bott NJ, Ophel-Keller KM, Sierp MT, Herdina and others (2010) Toward routine, DNA-based detection methods for marine pests. Biotechnol Adv 28:706-714

Burge EJ, Madigan DJ, Burnett LE, Burnett KG (2007) Lysozyme gene expression by hemocytes of Pacific white shrimp, Litopenaeus vannamei, after injection with Vibrio. Fish Shellfish Immunol 22:327-339

> Burge EJ, Burnett LE, Burnett KG (2009) Time-course analysis of peroxinectin mRNA in the shrimp Litopenaeus vannamei after challenge with Vibrio campbellii. Fish Shellfish Immunol 27:603-609

Burgents JE, Burnett LE, Stabb EV, Burnett KG (2005) Localization and bacteriostasis of Vibrio introduced into the Pacific white shrimp, Litopenaeus vannamei. Dev Comp Immunol 29:681-691

Bustin SA (2000) Absolute quantification of mRNA using real-time reverse transcription polymerase chain reaction assays. J Mol Endocrinol 25:169-193

Bustin SA (2002) Quantification of mRNA using real-time reverse transcription PCR (RT-PCR): trends and problems. J Mol Endocrinol 29:23-39

Bustin SA, Nolan T (2004) Pitfalls of quantitative real-time reverse-transcription polymerase chain reaction. J Biomol Tech 15:155-166

Coyne VE, James M, Reid S, Rybicki E (1996) Molecular biology techniques manual. University of Cape Town, Cape Town

DAFF (Department of Agriculture, Forestry and Fisheries) (2010) Marine aquaculture annual farm operation report 2010. Seriti Printing, Pretoria

Edwards K, Johnstone C, Thompson C (1991) A simple and rapid method for the preparation of plant genomic DNA for PCR analysis. Nucleic Acids Res 19:1349

Farrelly V, Rainey FA, Stackebrandt E (1995) Effect of genome size and rrn gene copy number on PCR amplification of 16S rRNA genes from a mixture of bacterial species. Appl Environ Microbiol 61:2798-2801

> Fuller MS, Fowles BE, McLaughlin DJ (1964) Isolation and pure culture study of marine phycomycetes. Mycologia 56:745-756

Garrett RH, Grisham CM (eds) (1995) Biochemistry, Vol 1. Saunders College Publishing, Orlando, FL

Hermansson A, Lindgren PE (2001) Quantification of ammonia-oxidizing bacteria in arable soil by real-time PCR. Appl Environ Microbiol 67(2):972-976

> Hiney MP, Smith PR (1998) Validation of polymerase chain reaction-based techniques for proxy detection of bacterial fish pathogens: framework, problems and possible solutions for environmental applications. Aquaculture 162:41-68 
Karakousis A, Tan L, Ellis D, Alexiou H, Wormald PJ (2006) An assessment of the efficiency of fungal DNA extraction methods for maximizing the detection of medically important fungi using PCR. J Microbiol Methods 65:38-48

Lamour KH, Win J, Kamoun S (2007) Oomycete genomics: new insights and future directions. FEMS Microbiol Lett 274:1-8

Li S, Cullen D, Hjort M, Spear R, Andrews JH (1996) Development of an oligonucleotide probe for Aureobasidium pullulans based on the small-subunit rRNA gene. Appl Environ Microbiol 62:1514-1518

> Li S, Spear RN, Andrews JH (1997) Quantitative fluorescence in situ hybridization of Aureobasidium pillans on microscope slides and leaf surfaces. Appl Environ Microbiol 63:3261-3267

Ma Z, Michailides TJ (2007) Approaches for eliminating PCR inhibitors and designing PCR primers for the detection of phytopathogenic fungi. Crop Prot 26:145-161

Macey BM, Achilihu IO, Burnett KG, Burnett LE (2008a) Effects of hypercapnic hypoxia on inactivation and elimination of Vibrio campbellii in the eastern oyster, Crassostrea virginica. Appl Environ Microbiol 74:6077-6084

Macey BM, Rathburn CK, Thibodeaux LK, Burnett LE, Burnett KG (2008b) Clearance of Vibrio campbellii injected into the hemolymph of Callinectes sapidus, the Atlantic blue crab: the effects of prior exposure to bacteria and environmental hypoxia. Fish Shellfish Immunol 25: 718-730

Macey BM, Christison KW, Mouton A (2011) Halioticida noduliformans isolated from cultured abalone (Haliotis midae) in South Africa. Aquaculture 315:187-195

Nakayama T, Watanabe S, Mitsui K, Uchida H, Inouye I (1996) The phylogenetic relationship between the Chlamydomonadales and Chlorococcales inferred from 18SrDNA sequence data. Phycological Res 44:47-55

Editorial responsibility: Eugene Burreson, Gloucester Point, Virginia, USA
Oidtmann B, Schaefers N, Cerenius L, Söderhäll K, Hoffmann RW (2004) Detection of genomic DNA of the crayfish plague fungus Aphanomyces astaci (Oomycete) in clinical samples by PCR. Vet Microbiol 100:269-282

> Oliver JD (2005) The viable but nonculturable state of bacteria. J Microbiol 43:93-100

> Petersen AB, Rosendahl S (2000) Phylogeny of the Peronosporomycetes (Oomycota) based on partial sequences of the large ribosomal subunit (LSU rDNA). Mycol Res 104:1295-1303

Phadee P, Kurata O, Hatai K, Hirono I, Aoki T (2004) Detection and identification of fish-pathogenic Aphanomyces piscicida using polymerase chain reaction (PCR) with species-specific primers. J Aquat Anim Health 16: $220-230$

Sekimoto S, Hatai K, Honda D (2007) Molecular phylogeny of an unidentified Haliphthoros-like marine oomycete and Haliphthoros milfordensis inferred from nuclearencoded small- and large-subunit rRNA genes and mitochondrial-encoded cox2 gene. Mycoscience 48: 212-221

- Vandersea MW, Litaker RW, Yonnish B, Sosa E and others (2006) Molecular assays for detecting Aphanomyces invadans in ulcerative mycotic lesions. Appl Environ Microbiol 72:1551-1557

Wu Z, Wang XR, Blomquist G (2002) Evaluation of PCR primers and PCR conditions for specific detection of common airborne fungi. J Environ Monit 4:377-382

Yamamoto N, Kimura M, Matsuki H, Yanagisawa Y (2010) Optimization of a real-time PCR assay to quantitate airborne fungi collected on a gelatin filter. J Biosci Bioeng 109:83-88

> Zhou G, Whong WZ, Ong T, Chen B (2000) Development of a fungus-specific PCR assay for detecting low-level fungi in an indoor environment. Mol Cell Probes 14:339-348

Submitted: August 23, 2011; Accepted: March 13, 2012 Proofs received from author(s): June 1, 2012 